JPdK Volume 3 Nomor 2 Tahun 2021 Halaman 102-105

JURNAL PENDIDIKAN dan KONSELING

Research \& Learning in Primary Education

\title{
Analisis Kesalahan Siswa dalam Operasi Hitung Perkalian Bersusun di SD Muhamadiyah 1 Paron berdasarkan Gender
}

\author{
Farahdila Damayanti ${ }^{1}$, Dany Febriana ${ }^{2}$, Rully Devita Sari ${ }^{3}$, Heni Yunita Wardani ${ }^{4}$, Darmadi $^{5}$ \\ Fakultas Keguruan dan Ilmu Pendidikan Universitas PGRI Madiun 1,2,3,4,5 \\ e-mail : mymayasmp@gmail.com ${ }^{1}$, danyfebriana16@gmail.com ${ }^{2}$, rullydevitasari6@gmail.com ${ }^{3}$, \\ heniynt15@gmail.com ${ }^{4}$, darmadi7868482@yahoo.com ${ }^{5}$
}

\begin{abstract}
Abstrak
Tujuan dari penelitian ini adalah mengetahui apa saja kesalaan diswa dalam menghitung perkalian besusun di SD Muhammadiyah 1 Paron yang didasarkan pada gender. Metode penelitian ini adalah deskriptif kualitatif, yang menggambarkan objek atau fakta sebenarnya secara sistematis. Pengumpulan data dilakukan dengan pemberian angket dan wawancara langsung kepada siswa dari SD Muhammadiyah 1 Paron. Subjek penelitian ini 2 perserta didik dari SD Muhammadiyah 1 Paron. Hasil penelitian menunjukkan bahwa masih adanya kesalahan yang dilakukan siswa, baik perempuan maupun laki-laki dalam operasi perkalian bersusun. Kesalahan ini rata-rata pada operasi hitung perkalian berususn, kurangya pemahampan konsep operasi hitung perkalian berususn yang diberikan guru kepada siswa hingga mengakibatkan kekeliruan operasi hitung khususnya perkalian.
\end{abstract}

Kata kunci: operasi hitung, perkalian bersusun, dan pemahaman konsep

\begin{abstract}
The purpose of this study was to find out what were the students' mistakes in calculating the multiplication of stacking at SD Muhammadiyah 1 Paron based on gender. This research method is descriptive qualitative, which describes the actual object or fact systematically. Data was collected by giving questionnaires and direct interviews to students from SD Muhammadiyah 1 Paron. The subjects of this study were 2 students from SD Muhammadiyah 1 Paron. The results showed that there were still errors made by students, both male and female, in multiplication operations. This error is on average in the multiplication arithmetic operation, the lack of understanding of the concept of multiplication counting operations given by the teacher to students, resulting in errors in arithmetic operations, especially multiplication.
\end{abstract}

Keywords: arithmetic operations, multiplication, and concept understanding

\section{PENDAHULUAN}

Artikel ini ditulis untuk melengkapi tugas mata kuliah analisis riil yang diampu oleh dosen kami Dr. Darmadi, S.Si.,M.Pd. Judul dari jurnal ini kami ambil dari permasalahan yang banyak terjadi di tingkat sekolah dasar. Pada dasarnya, pembelajaran matematika sangat penting sehingga jam pelajaran matematika juga tetap dimaksimalkan (Waluyo Adi, 2014). Mengingat matematika merupakan suatu mata pelajaran yang diajarkan di sekolah-sekolah dengan frekuensi jam pelajaran yang lebih banyak dibanding dengan mata pelajaran yang lainnya, namum masih banyak peserta didik yang merasa kurang mampu dalam mempelajari matematika karena dianggap sulit. Guru kurang memperhatikan peserta didik yang kurang mengerjakan soal dengan baik, hal ini dapat membuat peserta didik mengalami kesulitan dalam meyelesaikan soal-soal yang diberikan oleh guru. Masih banyak peserta didik yang salah dalam menentukan hasil perkalian dengan cara bersusun baik peserta didik laki-laki maupun perempuan. Istilah "kesalahan" dalam penelitian ini adalah padanan kata "error" dalam matematika. Kata kesalahan berasal dari kata salah yang berarti "tidak benar". Kesalahan adalah penyimpangan yang bersifat sistematis, konsisten dan menggambarkan kemampuan peserta didik pada tahap tertentu (Baradja, 1981: 12). Kesalahan dalam pengerjaan ini terjadi karena kurangnya pemahaman konsep yang dimilki setiap peserta didik. Kesalahan yang dilakukan oleh peserta didik dalam menyelesaikan soal matematika menunjukkan bahwa peserta didik tersebut belum 
berhasil dalam belajar matematika. Menurut Norrish (dalam Firmawati, 2013: 5), kesalahan bersumber pada beberapa hal: 1) pemilihan bahan ajar yang kurang menarik minat peserta didik dapat menyebabkan kesalahan, 2)pengajaran, kesalahan juga dapat disebabkan oleh cara mengajar guru yang kurang menarik dan menyenangkan serta pemaparan materi yang sulit untuk dipahami, 3)kesalahan yang bersumber dari peserta didik itu sendiri, misalnya tidak memperhatikan guru pada saat proses pembelajaran berlangsung. Artikel ini juga dibuat untuk melakukan penelitian faktor apa saja yang dapat menyebabkan siswa mengalami kesulitan dalam menentukan hasil dari perkalian dengan cara bersusun. Mengingat bahwa perkalian sangat penting sekali untuk dikuasai siswa sekolah dasar karena perkalian merupakan hitungan yang paling dominan dalam kehidupan sehari-hari.

Menurut Firmawati (2013: 6), analisis kesalahan dapat digunakan oleh guru untuk: 1) Menentukan penekanan-penekanan dalam hal penjelasan maupun latihan soal, 2) Memperbaiki metode pengajaran, 3) Memperbaiki pengajaran remedial, 4) Mengevaluasi penggunaan bahasa peserta didik.

Menurut Corder (dalam saad, mohammad azannee haji, 2014: 346) pengetahuan tentang kesalahan yang dihasilkan oleh peserta didik dapat membantu memberikan gambaran perkembangan pengetahuan peserta didik. Ini dapat mengarah pada pembuatan dan perencanaan materi pembelajaran dengan menggunakan bahasa yang lebih efektif. Oleh karena itu, melakukan analisis kesalahan yang dilakukan oleh peserta didik telah menjadi aspek penting dari proses pembelajaran.

Dalam Kamus Besar Bahasa Indonesia (2008: 59), analisis adalah penyelidikan terhadap suatu peristiwa untuk mengetahui apa sebabsebabnya, bagaimana duduk perkaranya, dan sebagainya. Sedangkan kesalahan dalam Kamus Besar Bahasa Indonesia (2008: 1345) adalah perilaku salah, kekeliruan tidak sengaja. Jadi, analisis kesalahan adalah sebuah upaya penyelidikan terhadap suatu kesalahan dari penyimpangan untuk mengetahui jenis dari penyimpangan tersebut.

Guru yang menuntut peserta didik untuk menguasai semua materi yang diberikan menjadikan peserta didik kesulitan dalam memahami konsep perkalian, karena banyak sekali materi yang diberikan namun peserta didik hanya menerima tanpa tahu asalnya dari mana. Selain itu, tuntutan penyelesaian materi pada waktu tertentu yang menyebabkan peserta didik harus dengan cepat menyelesaiakan materi tanpa harus paham secara betul materi yang disampaikan. Tidak hanya faktor tuntutan dari guru namun kurang aktifnya peserta didik dalam pelaksanaan kegiatan belajar di kelas juga menjadikan faktor mengapa siswa tidak dapat menghitung perkalian dengan hasil yang benar, karena seringkali ditemui bahwa peserta didik asik sendiri dalam kegiatan belajar.

Hitung atau menghitung memiliki arti membilang (menjumlahkan, mengurangi, membagi, memperbanyak, dan sebagainya). Kata "hitung" yang mendapat awalan me-, akan menjadi kata kerja "menghitung" yang berarti: (1) mencari jumlahnya (sisanya, pendapatannya) dengan menjumlahkan, mengurangi, dsb; (2) membilang untuk mengetahui berapa jumlahnya (banyaknya); (3) menentukan atau menetapkan menurut (berdasarkan) sesuatu.16 Kata untuk "menghitung" dalam bahasa Inggris adalah "to calculate" yang berarti; "To determine the value of something or the solution to something by a mathematical process; To plan something, especially something morally wrong."17 (Menetukan nilai dari sesuatu atau solusi dari sesuatu melalui proses matematika; menentukan nilai atau solusi melalui proses matematika; untuk merencanakan sesuatu, khususnya sesuatu yang secara moral salah). Dari pengertian diatas dapat disimpulkan bahwa operasi hitung adalah suatu perbuatan untuk menentukan nilai atau solusi sesuatu hal melalui proses matematika yaitu proses menjumlahkan, mengurangi, mengalikan, membagi, dan sebagainya.

Keadaan seperti ini sedikit banyak akan mengangggu kelancaran pembelajaran dan juga kreativitas peserta didik dalam menyelesaikan soalsoal perkalian yang diberikan oleh gurunya. Jika hal ini dibiarkan terus maka menyebabkan siswa mengalami kesalahan dalam mempelajari, memahami konsep, dan menyelesaikan soal-soal perkalian dengan bersusun.

Artikel mengaalisis kesalahan peserta didik berdasarkan gender. Gender sering diidentikkan dengan jenis kelamin (sex), padahal gender berbeda dengan jenis kelamin. Gender sering juga dipahami sebagai pemberian dari Tuhan atau kodrat Ilahi, padahal gender tidak semata-mata demikian. Menurut John M. Echols dan Hassan Shadily (1983), secara etimologis kata 'gender' berasal dari bahasa Inggris yang berarti jenis kelamin. Sedangkan menurut Victoria Neufeldt (1984), kata gender diartikan sebagai perbedaan yang tampak antara laki-laki dan perempuan dalam hal nilai dan perilaku. Gender merupakan ciri-ciri, sifat, peran, tanggung jawab serta posisi perempuan dan laki-laki yang dibentuk (dikonstruksikan) secara social.

Dari beberapa definisi tentang gender di atas dapat ditarik sebuah kesimpulan bahwa gender adalah 
suatu sifat yang dijadikan dasar untuk mengidentifikasi perbedaan antara laki-laki dan perempuan dilihat dari segi kondisi sosial dan budaya, nilai dan perilaku, mentalitas dan emosi, serta faktor-faktor nonbiologis lainnya.

Sumber kesulitan yang dihadapi peserta didik harus segera mendapat penyelesaian secara tuntas. Penyelesaian secara tuntas ini ditempuh dengan cara menganalisis akar permasalahan yang menjadi kesulitan siswa dalam mengerjakan soal matematika. Selanjutnya diupayakan langkahlangkah penyelesaian secara terstruktur dan sistematis sehingga diharapkan siswa dapat menyelesaikan belajarnya secara tuntas atau meminimalkan kesalahan yang dilakukan.

\section{METODOLOGI PENELITIAN}

Penelitian ini menggunakan metode deskriptif kualitatif yang menggambarkan situasi atau objek dalam fakta yang sebenarnya secara sistematis. Penelitian kualitatif merupakan metode penelitian naturalistic dikarenakan penelitiannya dilaksanakan pada kondisi yang apa adanya (natural setting) (Sugiyono, 2015) Pengumpulan data dilakukan dengan cara wawancara dan memberikan tes secara langsung kepada siswa sekolah yang dituju. Lokasi penelitian adalah Sekolah Dasar yang berada di Daerah Ngawi tepatnya SD Muhammadiyah 1 Paron Wawancara dilakukan pada hari antara senin-Jum "at pada minggu kedua Bulan Juni.

\section{HASIL PENELITIAN DAN PEMBAHASAN}

Berdasarkan Analisis data hasil tes dan hasil wawancara, diperoleh kesalahan-kesalahan yang dilakukan oleh siswa dalam menyelesaikan soal perkalian bersusun yaitu kesalahan konseptual dan kesalahan prosedural.

Kesalahan konsep yang dilakukan peserta didik yaitu dengan mengalikan dengan angka yang tidak seharusnya dan bingung dalam menjumlahkan sisa angka pengalinya. Kesalahan tersebut dilakukan Subjek 1 (Peserta didik perempuan) terhadap soal nomor 3 dan 5 yang terdapat dalam gambar berikut :

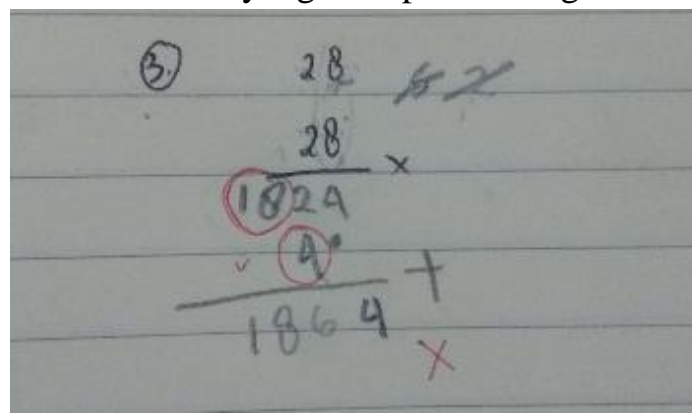

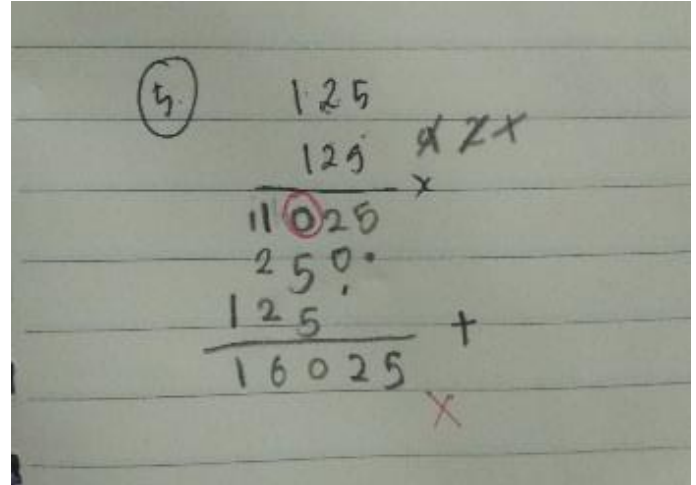

Selanjutnya, penulis akan melakukan wawancara dengan Subjek 1 untuk mengetahui jawaban yang tertera pada gambar 1 dan 2. Hasil wawancara disajikan berikut. Peneliti : Coba lihat soal nomor 3 dan 5

Subjek 1 : Iya bu bagaimana?

Peneliti : Apakah perhitungannya sudah benar?

Subjek 1: Saya tidak yakin bu, saya bingung bagaimana cara mengerjakannya dan saya tidak hafal perkalian

Berdasarkan hasil wawancara dengan peserta didik subjek 1 sangat jelas terlihat bahwa peserta didik tersebut belum memahami konsep dari perkalian bersusun. Sehingga, subjek 1 melakukan kesalahan dalam menyelesaikan perkalian bersusun. Kesalahan berikutnya yaitu kesalahan prosedural di mana peserta didik melakukan kesalahan dalam menerapkan konsep perkalian bersusun.

Kesalahan tersebut dilakukan oleh subjek 2 (peserta didik laki-laki) terhapad soal nomor (1) dan (2) yang terdapat dalam gambar berikut :
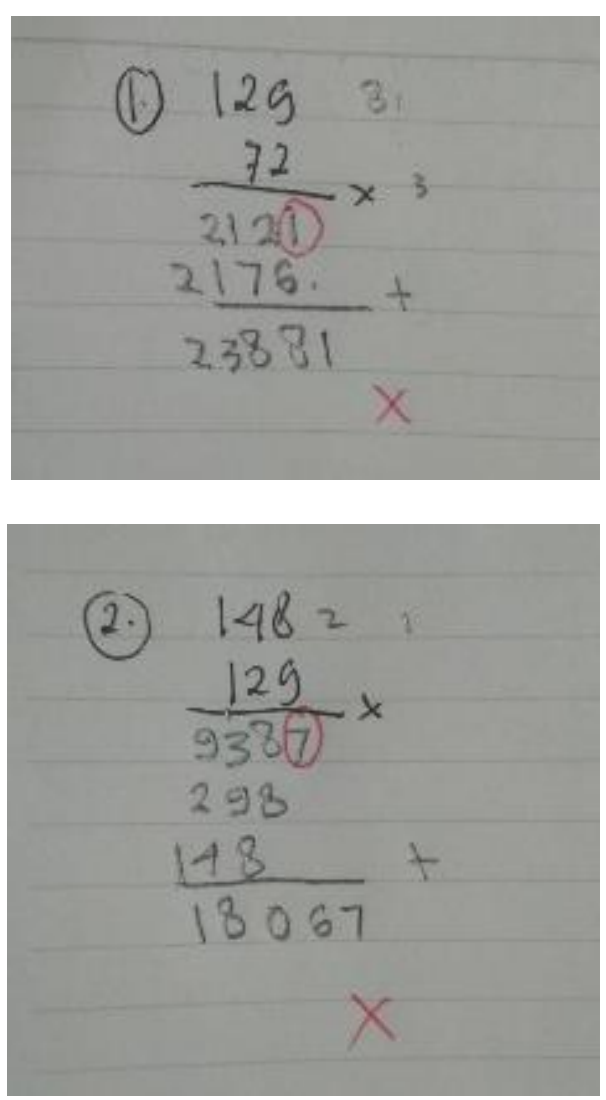

Selanjutnya, penulis akan melakukan wawancara dengan subjek 2 untuk mengetahui jawaban yang tertera pada gambar dibawah ini. Hasil wawancara disajikan berikut. 
Peneliti : Apakah kamu yakin dengan jawabanmu?

Subjek 2: Mungkin bu, soalnya saya lupa caranya bu Peneliti : Lupa bagaimana?

Subjek 2: Saya lupa bagimana cara mengerjakannya bu, soalnya saya bingung untuk angka yang ditaruh diperkalian bersusun itu angka depan atau angka belakang

Dari pernyataan tersebut kesalahan peserta didik terletak pada saat mengoperasikan pengerjaan hitungnya. Karena dari awal prosedur pengerjaannya salah maka, hasil jawabannya pun tidak tepat.

Pada pembahasan yang telah diuraikan dapat dilihat masalah-masalah yang timbul adalah kurangnya pemahaman siswa pada materi tersebut serta masih rendanya kemampuan berpikir siswa dalam proses operasi hitung perkalian bersusun. Selanjutnya kesalahan-kesalahan tersebut harus diperbaiki supaya tidak berkelanjutan dijenjang berikutnya.

Berdasarkan hasil penelitian tersebut maka dapat ditemukan bahwa siswa dengan kesulitan konsep dan kesulitan verbal dalam menyelesaikan masalah operasi hitung perkalian bersusun baik itu dari konsep maupun procedural. Dengan demikian maka faktor yang menjadi penyebab terjadinya kesalahan siswa dalam menyelesaikan operasi hitung perkalian bersusun adalah masih rendahnya pemahaman siswa.

\section{SIMPULAN}

Berdasarkan pembahasan dari hasil penelitian yang sudah selesai dilakukan, dapat disimpulkan bahwa faktor penyebab banyaknya kesalahan dalam menjawab soal, diantaranya :

a. Kurangnya pemahaman konseptual terhadap operasi perkalian

b. Kurangnya pengerjaan secara prosedural dalam mengoperasikan perkalian

c. Kurang teliti dalam mengoperasikan operasi hitungnya

Pemahaman konsep yang salah pada peserta didik mengenai operasi perkalian bersusun, membuat peserta didik semakin memiliki banyak melakukan kesalahan dalam menjawaban soal. Diharapkan selain memberikan konsep yang baik, guru juga bisa memberikan motifasi pada peserta didik agar lebih teliti dan hati-hati dalam menjawab soal.

\section{DAFTAR PUSTAKA}

A S Hornby. Advanced Learner's Dictionary of Current English. (London; Oxford University
Press, 1983), 119

Dwi Narwoko \& Bagong Suyanto (ed). Sosiologi: Teks Pengantar \& Terapan, (Jakarta: Prenada Media, 2004), 313-339.

Hasan Alwi, dkk. Kamus Besar Bahasa Indonesia Edisi ke-3. (Jakarta; Balai Pustaka, 2007), 405

John M. Echols dan Hassan Shadily, Kamus Inggris Indonesia, (Jakarta: Gramedia, 1983), 265

Kurnianti sri, dkk. (2017) ANALISIS KESALAHAN SISWA KELAS V SD NEGERI 8 MAMBORO PALU UTARA DALAM MENYELESAIKAN SOAL PERKALIAN DAN PEMBAGIAN PECAHAN. Jurnal Elektronik Pendidikan Matematika Tadulako, Volume 04 Nomor 04, Juni 2017

Sugiyono. (2015). Metode Penelitian Pendidikan (Pendekatan Kuantitatif, Kualitatif, dan R\&D). Bandung: Alfabeta

Victoria Neufeldt, (ed.), Webster's New World Dictionary, (New York: Webster's New World Clevenland, 1984), 561.

Waluyo adi, Kristanti dian. (2014). ANALISIS KESALAHAN SISWA DALAM MENYELESAIKAN SOAl MATEMATIKA PADA POKOK BAHASAN PERSAMAANLINEAR DUA VARIABEL DI KELAS VIII SMPNEGERI 5 KUALA. MAJU, Volume 1 No 2, September 2014 